\title{
Novel approaches to identify protective malaria vaccine candidates
}

\author{
Wan Ni Chia ${ }^{1,2}$, Yun Shan Goh ${ }^{1}$ and Laurent Rénia ${ }^{1,2}$ * \\ 1 Singapore Immunology Network, Agency for Science, Technology and Research, Singapore, Singapore \\ ${ }^{2}$ Department of Microbiology, Yong Loo Lin School of Medicine, National University of Singapore, Singapore, Singapore
}

\section{Edited by:}

Urszula Krzych, Walter Reed Army

Institute of Research, USA

\section{Reviewed by:}

Julius Clemence Hafalla, London

School of Hygiene and Tropical

Medicine, UK

Stasya Zarling, Walter Reed Army

Institute of Research, USA

\section{*Correspondence:}

Laurent Rénia, Singapore

Immunology Network, Agency for

Science, Technology and Research,

8a Biomedical Grove, Immunos,

Biopolis, 138648 Singapore,

Singapore

e-mail: renia_laurent@immunol.

a-star.edu.sg

\begin{abstract}
Efforts to develop vaccines against malaria have been the focus of substantial research activities for decades. Several categories of candidate vaccines are currently being developed for protection against malaria, based on antigens corresponding to the preerythrocytic, blood stage, or sexual stages of the parasite. Long lasting sterile protection from Plasmodium falciparum sporozoite challenge has been observed in human following vaccination with whole parasite formulations, clearly demonstrating that a protective immune response targeting predominantly the pre-erythrocytic stages can develop against malaria. However, most of vaccine candidates currently being investigated, which are mostly subunits vaccines, have not been able to induce substantial $(>50 \%)$ protection thus far. This is due to the fact that the antigens responsible for protection against the different parasite stages are still yet to be known and relevant correlates of protection have remained elusive. For a vaccine to be developed in a timely manner, novel approaches are required. In this article, we review the novel approaches that have been developed to identify the antigens for the development of an effective malaria vaccine.
\end{abstract}

Keywords: malaria, vaccine, library, antibodies, screen

\section{INTRODUCTION}

Malaria is an infectious disease caused by the protozoan parasite Plasmodium and transmitted by the Anopheles mosquitoes. Malaria is a major public health problem, leading to high mortality and morbidity. Nearly half the world's population is at risk of contracting malaria (CDC, 2012). There are 207 million cases of clinical malaria and approximately 627,000 deaths in WHO (2012). There is currently no available vaccine. Age and host immune status are high risk factors for malaria, with young children under the age of five, pregnant women and travelers or migrants who lack immunity to the disease being most susceptible. Other risk factors include the infectivity and the transmission dynamics of the parasite strain (Doolan, 2011).

The Plasmodium parasite has a complex life cycle. Following an infected mosquito bite, sporozoites are inoculated into the dermis of the mammalian host (Vanderberg and Frevert, 2004; Amino et al., 2006). The sporozoites travel to the liver via the bloodstream and infect the hepatocytes (Amino et al., 2006). During this phase in the hepatocytes, sporozoites develop into schizonts over 2-14 days, depending on the species. Merosomes, merozoites containing vesicles, eventually bud out from infected hepatocytes to release merozoites, which then infect erythrocytes (Sturm et al., 2006; Baer etal., 2007). Some of the blood stage parasites undergo sexual differentiation into male and female gametocytes that can be taken up by a feeding Anopheline during a blood meal. Ookinetes, which results from gametocyte fusion, develop into oocysts in the midgut of the mosquito. Upon oocyst maturation, newly formed sporozoites migrate to the salivary gland of the mosquito, awaiting the next blood meal (Moorthy et al., 2004).
Symptoms of malaria include fever, headache, chills, sweating, and vomiting. Recurrent fever is one of the hallmarks of clinical malaria. This is a consequence of the release of malarial toxins into the bloodstream following repetitive rupture and re-invasion of erythrocytes. With disease progression, the red blood cell counts decreases and severe anemia might occur. Malarial infected red blood cells, such as those of Plasmodium falciparum, can also sequester in deep tissues, causing cerebral malaria, and organ failure. These severe pathologies can eventually lead to death.

\section{IMMUNE RESPONSES TO A MALARIA INFECTION}

Protective immunity against malaria requires a timely and coordinated interplay between the innate and adaptive immunity. This involves dendritic cells, NK cells, B cells, $\mathrm{CD} 4^{+}$and $\mathrm{CD} 8^{+} \mathrm{T}$ cells (Stevenson and Riley, 2004).

Sporozoite-specific antibodies can block sporozoites from migrating to the liver or from invading into hepatocytes, arresting disease progression (Rathore et al., 2005; Finney et al., 2014). Antibody-mediated immunity has been thought to be the central effectors of parasite clearance in the peripheral blood as MHC class I/II molecules are absent on the surface of infected red blood cells (Langhorne et al., 2008). The importance of antibodies was first demonstrated by Cohen et al. (1961), showing that passive transfer of immunoglobulins from immune adults into naïve, infected children resulted in rapid reductions of parasite density and resolution of clinical symptoms (Cohen et al., 1961). Merozoite-specific antibodies can prevent merozoites from invading erythrocytes (Michon et al., 2000; Dutta et al., 2005; Jiang et al., 2011) and mediate clearance of infected red blood cells by phagocytic cells via antibody-dependent cellular inhibition (Marsh and 
Kinyanjui, 2006). Pathogen-specific antibodies secreted by B cells with $\mathrm{CD} 4^{+} \mathrm{T}$ helper cells enhancement are essential for clearance of parasitemia in the later stages of the infection (Langhorne et al., 2008).

In addition to the humoral arm of the adaptive immunity, cell-mediated immune responses are also crucial for protection against malaria. $\mathrm{CD}^{+}$and $\mathrm{CD}^{+}{ }^{+} \mathrm{T}$ cells kill infected hepatocytes through diverse mechanisms (Renia etal., 1993; Doolan and Hoffman, 2000; Frevert et al., 2009; Trimnell et al., 2009; Cockburn et al., 2013) and induce sterile protection (i.e., no blood stage infection) in mouse models. Recent work has revealed an important role for IFN $\gamma$-secreting $\mathrm{CD}^{+} \mathrm{T}$ cells in preventing chronic $P$. chabaudi blood stage infection in mice (Horne-Debets et al., 2013). In human, sterile protection has been observed in experimental sporozoite challenge experiments following vaccination with whole sporozoites (Hoffman et al., 2002; Roestenberg et al., 2009; Seder et al., 2013). Both sporozoite-specific antibodies and $\mathrm{T}$ cells were induced.

\section{VACCINE DEVELOPMENT AGAINST MALARIA}

The rationale for vaccine development to protect against malaria stems from observations where naturally acquired immunity to malaria can protect individuals living in malaria-endemic regions against malaria in an age-dependent and exposuredependent manner (Gupta et al., 1999; Schofield and Mueller, 2006; Crompton et al., 2010). Although the protection is not sterilizing and is not always ensured for all chronically exposed individuals, passive transfer of sera from some chronically exposed individuals reduced strongly parasite levels in infected individuals (Cohen et al., 1961; Bouharoun-Tayoun et al., 1995). This demonstrated that antibodies can offer protection against the blood phase of the malarial infection.

More rationally, the typical Pasteur approach where attenuated parasites were used as vaccines has further demonstrated the feasibility of vaccination as protection against malaria. Immunization with irradiation-attenuated sporozoites has shown to confer sterile immunity against sporozoites challenge in animal models and in humans (Richards, 1966; Nussenzweig et al., 1967; Clyde et al., 1973; Rieckmann et al., 1974; Hoffman et al., 2002). The protective immune response involving antibodies and $\mathrm{T}$ cells was shown to target the pre-erythrocytic stages (Nussenzweig et al., 1967; Overstreet et al., 2008). In recent years, immunization with sporozoite or blood parasite under drug cover was also shown to confer strong protective immunity involving antibodies and $\mathrm{T}$ cells (Belnoue et al., 2002; Renia et al., 2006; Roestenberg et al., 2009; Friesen et al., 2010). Other approaches have used genetically attenuated parasites. Although these approaches have led to sterile immunity in mice (Mueller et al., 2005; Butler et al., 2012), they have yet to prove their efficacy in humans (Spring et al., 2013).

After decades of efforts spent on developing vaccines against malaria, no strong vaccine candidate has emerged as yet. Most vaccine development efforts are focused on only four antigens (WHO, 2012). The most clinically advanced candidate, RTS,S, conferred $\sim 50 \%$ protection from clinical $P$. falciparum malaria in children aged $5-17$ months, and $\sim 30 \%$ protection in children aged 6-12 weeks (Agnandji et al., 2011, 2012). Vaccine efficacy was undetectable 3 years after vaccination (Bejon et al., 2013). This level of protection is suboptimal and too low to achieve malaria eradication. No single molecular signature, key cellular determinant or immune mechanism of naturally acquired or vaccine-induced immunity has been unequivocally associated with protection (Offeddu et al., 2012). This impediment toward vaccine development for malaria is multi-factorial. The Plasmodium parasite has a diverse protein repertoire, and a complex life cycle involving both vertebrate and invertebrate hosts. There are antigenic polymorphisms and variations across parasite strains and species, and the parasite has developed sophisticated strategies to evade the host immunity.

With more reports of drug resistance and insecticide resistance in some endemic regions (Trape et al., 2011; Phyo et al., 2012; Ashley et al., 2014), management of the malarial disease has been increasingly difficult. Identification of new malarial antigens for vaccine development is critical. Here, we reviewed the different techniques that have been used to identify antigens recognized by antibodies induced during natural infections or after vaccinations with whole parasites.

\section{PRE-GENOMIC SCREENING METHODS FOR PROTECTIVE ANTIGENS}

The advent of new molecular biology techniques in the 1980s led to the discovery of many Plasmodium antigens. DNA libraries, consisting of cDNA or genomic DNA, were constructed in bacteriophage vectors for expression in Escherichia coli (Kemp et al., 1986). Antigens such as the circumsporozoite protein (CSP), the S-antigen, the ring erythrocyte surface antigen (RESA) were the first to be identified using mouse monoclonal antibodies (Ellis et al., 1983), sera from infected humans (Kemp et al., 1983; Stahl et al., 1984) or sera from infected mice or monkeys (Anders et al., 1984; Brown et al., 1984; Ardeshir et al., 1985). All the antigens discovered using these approaches were immunodominant or possessed immunodominant regions made of repeats (Kemp et al., 1987). Although immunodominant antigens induce very strong antibody responses, recent studies have shown that they did not offer adequate protection when tested as subunit vaccines in clinical trials (Spring et al., 2009; Doolan, 2011; Sheehy et al., 2012), suggesting that these antigens might be used by the Plasmodium parasite for immune evasion (Anders, 1986; Rodriguez et al., 2008). The CSP, an antigen of pre-erythrocytic stage malaria and the first malaria antigen to be cloned (Ellis et al., 1983), is one such example. Despite being immunodominant, the Phase III vaccine efficacy was suboptimal, with 55\% reduction in the frequency of malaria episodes during the 12 months of follow-up in children 5-17 months of age and 35\% in children 6-12 weeks old at first immunization (Agnandji et al., 2011). The protection waned to a mere $16.8 \%$ after 4 years of follow-up, indicating the lack of long lasting protection which declined with time and exposure to the parasite (Olotu et al., 2013). Similarly, while immunization with the apical membrane antigen-1 (AMA-1), an antigen expressed both at the pre-erythrocytic and erythrocytic stages and strongly immunodominant during the erythrocytic stage, elicited functional antibodies with in vitro inhibition against homologous blood parasites, volunteers developed parasitemia upon challenge with controlled human malaria infection (infection by mosquito 
bites) without a significant reduction of peak parasitemia nor delay to patency (Spring et al., 2009).

The cDNA library approach is advantageous with a good representation of a stage-specific Plasmodium proteome, depending on the stage of the parasite at which the RNA was extracted from. However, the repertoire of the Plasmodium proteome the cDNA library represents is not entirely comprehensive and does not include antigens expressed by the parasite in the other stages of its life cycle. Nevertheless, it has successfully identified more than a hundred malaria antigens. Recently, Raj et al. (2014) created a $P$. falciparum blood stage cDNA library constructed in bacteriophage and expressed in E. coli. The antigen library was screened against sera from either infection-resistant or - susceptible chronically exposed individuals living in malaria-endemic regions. 2 out of 3 antigens identified were novel antigens. Antibody to one of the identified novel antigens, PfSEA-1, inhibited parasite growth and blocked schizont egress. Using the P. berghei ANKA strain ortholog of PfSEA-1, the authors demonstrated reduced parasitemia and longer survival in mice vaccinated with PbSEA-1. They further validated PfSEA-1 as a promising vaccine candidate through epidemiological studies, where anti-PfSEA-1 antibodies were strongly associated with lesser incidence of severe malaria in Tanzanian children and lower level of parasitemia in Kenyan adults.

\section{SCREENING METHODS TO IDENTIFY NEW ANTIGENS IN THE ERA FOLLOWING GENOME SEQUENCING}

At the turn of the 20th century, whole genomes of many Plasmodium strains were sequenced. These genome sequencing initiatives, by The Wellcome Trust Sanger Institute and The Institute for Genomic Research, have provided a wealth of data for the identification of protective antigens (Carlton et al., 2002; Gardner et al., 2002). In this review, we discuss the novel approaches (summarized in Table 1) to screen libraries of malarial antigen using sera from protected versus unprotected individuals to identify antigens associated with protection, in search for new protective antigens for vaccine development against malaria.

\section{NEW APPROACHES TO SEARCH FOR ANTIGENS INVOLVED IN PROTECTION}

The availability of whole genome sequences has enhanced the understanding of the parasite biology. Protein functions can be predicted and validated. Potential antigens could be screened for specific characteristics such as surface expression. Comparative genomics between different parasite strains allows identification of antigens that have limited variation, with the promise of greater vaccine coverage and hence efficacy in the field (Kooij etal., 2005).

Transcriptomics and proteomics has provided critical information on the expression profiles of malarial proteins during the parasite's life cycle (Florens et al., 2002; Le Roch et al., 2002; Bozdech etal., 2003; Hall etal., 2005) - the mosquito stage (Lindner et al., 2013), the liver stage (Tarun et al., 2008), and the sexual stage (Lasonder etal., 2002; Khan et al., 2005). In silico analysis of stage-specific transcription pattern identifies antigens that are differentially expressed for specific targeting to a specific stage of the parasite's life cycle and also antigens with conserved expression across the different stages for cross-stages targeting (Florens et al., 2002).

\section{SCREENING RECOMBINANT PROTEIN MICROARRAYS AGAINST IMMUNE SERA FROM VACCINATED HUMAN INDIVIDUALS}

Using the published $P$. falciparum and $P$. vivax genomes, a set of selected genes was targeted for protein expression using an in vitro transcription/translation system (Doolan et al., 2008; Tsuboi et al., 2008; Crompton et al., 2010; Barry et al., 2011; Trieu et al., 2011; Molina et al., 2012; Baum et al., 2013; Lu et al., 2014). These recombinant proteins were then printed onto microarray chips and probed with immune sera that were obtained from human volunteers naturally exposed to malaria infections or immunized with radiation-attenuated sporozoites. Doolan et al. (2008) generated a protein microarray with 250 P. falciparum proteins and used it to profile antibody responses in sera from four groups of individuals: (1) protected, (2) non-protected individuals following vaccination with radiation-attenuated sporozoites, (3) partially protected individuals due to natural exposure, and (4) non-exposed individuals. The same group then expanded their library to include 1204 P. falciparum proteins (representing 23\% of the P. falciparum genome; Crompton et al., 2010; Trieu et al., 2011; Baum et al., 2013) and also 91 P. vivax proteins (Molina et al., 2012). $22-29 \%$ of the screened proteins were found to be serodominant in immune sera, demonstrating a broad and varied response to many antigens. Antibody titres against current vaccine candidates such as CSP, atypical membrane antigen-1, liver stage antigen3 , merozoite surface protein-1 did not differ between immune and non-immune individuals (Crompton et al., 2010; Trieu et al., 2011).

Richards et al. (2013) expressed P. falciparum merozoite proteins, reported to have a role in erythrocyte invasion and/or localized on the merozoite surface or in the invasion organelles of the merozoites, in either bacterial or wheat germ cell-free expression systems. The recombinant proteins were tested for IgG immunoreactivity using sera from malaria-exposed Papua New Guinea children in ELISA. Forty six proteins were selected based on their ability to coat ELISA plates and their immunoreactivity. Sera from older children had higher immunoreactivity to most of the 46 proteins as compared to the younger children, indicating an acquisition of antibody responses with age, presumably due to prolonged exposure to the parasite. While merozoite surface proteins had higher seropositivity compared to the rhoptry and micronemal proteins, the antigens strongly correlated with protection were the rhoptry and micronemal proteins. This is consistent with other studies, suggesting that the key protective malarial antigens are the non-immunodominant antigens (Doolan et al., 2003, 2008; Crompton et al., 2010; Trieu et al., 2011; Baum et al., 2013). The authors proposed that a combinational vaccine consisting of non-immunodominant antigens, such as EBA, PfRh2 and PfRh4, is more likely to offer greater protection (Richards et al., 2013).

One of the main drawbacks with protein array is the extensive efforts needed to generate the soluble recombinant malarial antigens in the library (Doolan et al., 2008; Tsuboi et al., 2008). Cell-based expression systems have met with many difficulties. $P$. falciparum genes have a high $\mathrm{A} / \mathrm{T}$ content and a substantial number 
Table 1 | Approaches taken to identify protective malarial antigens for vaccine development.

\begin{tabular}{|c|c|c|c|c|c|c|}
\hline & $\begin{array}{l}\text { Type of antigen } \\
\text { library }\end{array}$ & $\begin{array}{l}\text { Antigen } \\
\text { expression } \\
\text { system }\end{array}$ & $\begin{array}{l}\text { Size of } \\
\text { library }\end{array}$ & $\begin{array}{l}\text { Type of } \\
\text { screening }\end{array}$ & $\begin{array}{l}\text { Sera/antigens that library } \\
\text { is screened against }\end{array}$ & Reference \\
\hline \multirow[t]{3}{*}{ Pre-genomic era } & cDNA & E. coli cell-based & & $\begin{array}{l}\text { In vitro } \\
\text { immunoscreen }\end{array}$ & $\begin{array}{l}\text { Mouse monoclonal } \\
\text { antibodies }\end{array}$ & Ellis et al. (1983) \\
\hline & cDNA & E. coli cell-based & 10000 clones & $\begin{array}{l}\text { In vitro } \\
\text { immunoscreen }\end{array}$ & $\begin{array}{l}\text { Sera from infected human } \\
\text { individuals }\end{array}$ & $\begin{array}{l}\text { Kemp etal. (1983), } \\
\text { Brown etal. (1984), } \\
\text { Stahl et al. (1984) }\end{array}$ \\
\hline & cDNA & E. coli cell-based & $\begin{array}{l}10000 \text { clones } \\
10000 \text { clones } \\
9000 \text { clones }\end{array}$ & $\begin{array}{l}\text { In vitro } \\
\text { immunoscreen }\end{array}$ & $\begin{array}{l}\text { Sera from infected mice, } \\
\text { mice and rabbits, } \\
\text { monkeys }\end{array}$ & $\begin{array}{l}\text { Brown et al. (1984) } \\
\text { Anders et al. (1984) } \\
\text { Ardeshir et al. (1985) }\end{array}$ \\
\hline \multirow[t]{7}{*}{ Post-genomic era } & cDNA & E. coli cell-based & $\begin{array}{l}1250000 \\
\text { clones }\end{array}$ & $\begin{array}{l}\text { In vitro } \\
\text { immunoscreen }\end{array}$ & $\begin{array}{l}\text { Sera from infection-resistant } \\
\text { and-susceptible chronically } \\
\text { exposed human individuals }\end{array}$ & Raj et al. (2014) \\
\hline & $\begin{array}{l}\text { Recombinant } \\
\text { proteins }\end{array}$ & $\begin{array}{l}\text { E. coli cell-free in } \\
\text { vitro translation }\end{array}$ & 250 antigens & $\begin{array}{l}\text { In vitro } \\
\text { immunoscreen }\end{array}$ & $\begin{array}{l}\text { Sera from protected and } \\
\text { non-protected individuals } \\
\text { following vaccination with } \\
\text { radiation-attenuated } \\
\text { sporozoites }\end{array}$ & Doolan et al. (2008) \\
\hline & $\begin{array}{l}\text { Recombinant } \\
\text { proteins }\end{array}$ & $\begin{array}{l}\text { E. coli cell-based } \\
\text { and wheat germ } \\
\text { cell-free system }\end{array}$ & 46 antigens & $\begin{array}{l}\text { In vitro } \\
\text { immunoscreen }\end{array}$ & $\begin{array}{l}\text { Sera from malaria-exposed } \\
\text { children }\end{array}$ & Richards et al. (2013) \\
\hline & $\begin{array}{l}\text { Antigens } \\
\text { expressed on cell } \\
\text { surface }\end{array}$ & $\begin{array}{l}\text { Mammalian } \\
\text { cell-based }\end{array}$ & 80 antigens & $\begin{array}{l}\text { In vitro } \\
\text { immunoscreen }\end{array}$ & $\begin{array}{l}\text { Sera from protected and } \\
\text { non-protected individuals } \\
\text { following vaccination with } \\
\text { live sporozoites }\end{array}$ & Chia etal. (2014) \\
\hline & $\begin{array}{l}\text { Whole parasite } \\
\text { lysates }\end{array}$ & P. yoelii parasite & $\begin{array}{l}\text { Whole } \\
\text { proteome }\end{array}$ & $\begin{array}{l}\text { In vitro } \\
\text { immunoscreen }\end{array}$ & $\begin{array}{l}\text { Affinity-purified lgG from } \\
\text { immune mice that naturally } \\
\text { survived a lethal infection }\end{array}$ & Kamali et al. (2012) \\
\hline & DNA (exons) & - & 19 genes & $\begin{array}{l}\text { In vivo screen in } \\
\text { mice for } \\
\text { protection }\end{array}$ & - & Haddad et al. (2004) \\
\hline & $\begin{array}{l}\text { Recombinant } \\
\text { proteins }\end{array}$ & $\begin{array}{l}\text { Mammalian } \\
\text { cell-based }\end{array}$ & 51 antigens & $\begin{array}{l}\text { In vitro } \\
\text { protein-protein } \\
\text { interaction screen }\end{array}$ & Malarial antigen, PfRh5 & Crosnier et al. (2011) \\
\hline
\end{tabular}

of the genes encode stretches of repeat sequences (Gardner et al., 2002), hindering protein expression in cell-based expression system. Only 30\% out of 1000 genes investigated by Mehlin et al. (2006) can be expressed in E. coli and a mere 6.3\% of the proteins are soluble. The alternative is the wheat germ cell-free expression system. Tsuboi et al. (2008) were able to express 93 out of $124 P$. falciparum genes as soluble proteins using the wheat germ cellfree system. Rui et al. (2011) reported greater immunogenicity of wheat germ proteins (as opposed to identical proteins produced in E. coli) in mice. The wheat germ cell-free expression system could be more suitable for producing antigens for vaccine development.

\section{SCREENING CELL-ASSOCIATED ANTIGEN LIBRARIES AGAINST IMMUNE MOUSE SERA}

We recently cloned a library of 80 malarial antigens into a mammalian surface expression vector pDisplay (Invitrogen; Chia et al., 2014). They transfected these expression vectors into mammalian 
cells and the antigens were expressed on the cell surface, creating a library of antigen-presenting cells. The library was screened against immune and non-immune sera obtained from mice immunized with live sporozoites or blood parasites under drug cover (Belnoue et al., 2008). Similarly, all immunized volunteers in the study were protected from sporozoites challenge. The antibody repertoire of immunized volunteers was extremely broad and varied. MAEBL was found to be strongly associated with protection. MAEBL has been implicated in invasion into hepatocytes by sporozoites and merozoites into erythrocytes (Kappe et al., 1998, 2001). It was previously demonstrated that anti-MAEBL antibodies to inhibit $P$. yoelii sporozoites invasion in vitro in primary mouse hepatocytes, suggesting that MAEBL is a promising attractive vaccine candidate (Singh et al., 2004).

This approach removes the difficulty of expressing and purifying antigens as soluble recombinant proteins. However, the library size in this study represents a small representation of the entire Plasmodium genome $(\sim 1 \%)$ and antigens screened were mainly restricted to those with reasonably good transfection efficiency.

\section{SCREENING WHOLE PARASITE LYSATES AGAINST AFFINITY-PURIFIED IgG FROM NATURALLY SURVIVING MICE}

Due to ethical and technical restrictions, identification of protective immune correlates in humans can only be evaluated in the peripheral blood component. This hinders the study of a vital stage of the parasite's life cycle, the liver stage. It also limits the examination of the host immune responses in the secondary lymphoid organs such as the spleen, which are also important sites for the induction of protective immunity.

The use of comparative genomic analysis, through the construction of genome-wide synteny maps, has identified other non-human models of malaria (Carlton et al., 2002; Tachibana et al., 2012). Mouse models have played a vital role in the understanding of the immunobiology of malarial infections. The mouse malaria parasite, P. yoelii, has been used as a model for malaria research due to the substantial similarity to the human parasite P. falciparum (Hall et al., 2002). In addition to being cheaper to maintain and easier to handle, the mouse also has a well characterized immune system, hence offering great advantages over non-human primate models (Wykes and Good, 2009; TaylorRobinson, 2010). Infection studies of rodent malaria species and their hosts have provided information on parasite biology and pathogenicity. Identification of orthologs allows preclinical validation of new chemotherapies and vaccine candidates. The lethal P. yoelii model, which causes death in BALB/c mice, is an excellent model for investigating the vaccine efficacy of the candidates in vivo (Langhorne, 1994). Kamali et al. (2012) observed that 20\% of ICR mice infected with the lethal strain of $P$. yoelii cleared the infection and these naturally surviving mice had boosted immunity following a second challenge. They affinity-purified the IgG from these mice and probed against whole parasite lysates. Using MALDI-TOF analysis, the antigenic specificities of the protective IgG were Heat shock protein 70 (HSP70), protein disulphide isomerase, plasmepsin and a $39 \mathrm{kDa}$ subunit of eukaryotic translation initiation factor 3. Although the authors did not validate the protective potential of the identified antigens, the approach used in the study identified novel antigens (with the exception of
PfHSP70.1 (Haddad et al., 2004). Antibodies against PfHSP70.1 have been shown to eliminate in vitro liver stage parasites through antibody-dependent cell-mediated cytotoxic mechanisms (Renia et al., 1990).

\section{SCREENING FOR PROTECTIVE DNA VACCINE CANDIDATE IN MOUSE CHALLENGE MODEL}

New molecular technologies such as Gateway cloning make it easy to clone large numbers of genes into plasmids. Using this technology, Haddad et al. (2004) produced an expression library of 182 Plasmodium exons coding for pre-erythrocytic antigens in the mammalian immunization vector VR1012. They immunized mice with 19 out of the 182 cloned vectors, either singly or in combination, and assessed vaccine efficacy following sporozoites challenge by examining the ability of the immunized mice to reduce liver stage parasite load. The most promising DNA vaccine candidate identified was Py01316, annotated as a Qa-SNARE protein in PlasmoDB, which gave a $68-79 \%$ reduction in parasite load.

The approach taken by Haddad et al. (2004) has the benefit of generating a library of DNA vaccine candidates, targeting many Plasmodium genes with great ease, and does not require the laborious process of generating recombinant proteins. It also provides information on the immunogenicity of the DNA constructs and in vivo effectiveness of the induced immune responses to reduce parasite load. However, screening for protective DNA vaccine targets in mice is laborious and requires a large number of mice. As a result, the authors screened a total of 19 out of the 182 cloned plasmids, which limited the number of malarial antigens that can be validated for protective efficacy.

\section{TARGETED SCREENING TO IDENTIFY MALARIAL ANTIGENS AND THEIR RECEPTORS}

Crosnier et al. (2011) expressed a library of erythrocyte surface proteins with the mammalian expression system. Using the avidity-based extracellular interaction screen (AVEXIS), they screened recombinant PfRh5 protein (the bait protein), which is critical for erythrocyte invasion by merozoites, against the library of erythrocyte surface proteins (the prey protein). The PfRh5 protein was found to interact with only one erythrocyte surface protein, basin. The anti-basin monoclonal antibodies were highly effective at blocking $P$. falciparum invasion into erythrocytes $e x$ vivo and these blocking effects were efficacious with 15 other culture-adapted and field strains of $P$. falciparum. These data have implications for novel therapeutics. While this does not directly identify new protective malarial antigens for vaccine development, the identification of basin as the binding partner of PfRh5 and perhaps further characterisation studies on the expression levels of basin by the target population would provide critical information on the vaccine efficacy of PfRH5, should PfRh5 be developed as a vaccine candidate. Understanding how basigin binds to PfRh5 could also facilitate rational design of drug compounds to block $P$. falciparum's invasion into erythrocytes.

One of the shortcomings of AVEXIS is the generation of the library of recombinant proteins, which is laborious. This approach also requires the prior identification of a known bait protein, which is difficult for identifying novel host-parasite interacting antigen 
pairs. However, the AVEXIS assay is advantageous in its ability to detect direct low-affinity protein interactions, which might not be detectable in other screening methods. More recently, this type of library has shown to be a powerful tool to identify new protective antigens for potential vaccine target development. Using sera from a longitudinal study in a cohort of Kenyan children, Osier et al. (2014) identified 10 antigens (PF3D7_1136200, MSP2, RhopH3, P41, MSP11, MSP3, PF3D7_0606800,AMA1, Pf113, and MSRP1) that were associated with protection against clinical episodes of malaria. While the AVEXIS approach has been used to identify blood stage antigens in this study, the study could be extended to include antigens for other stages.

\section{IDENTIFICATION OF PROTECTIVE PRE-ERYTHROCYTIC ANTIGENS}

Pre-erythrocytic antigens have been attractive targets for vaccine development. This is mainly due to the demonstration that sterile immunity against malaria is achievable in experimental sporozoite challenge experiments in humans following vaccination with whole sporozoites (Hoffman et al., 2002; Roestenberg et al., 2009; Seder et al., 2013).

Most of the above described approaches for identification of protective antigens have used sera from chronically exposed individuals living in endemic regions to screen for protective malarial antigens. Although the approaches have identified mainly blood stage antigens, some of the identified blood stage antigens, such as AMA1 (Silvie et al., 2004), TRAP (Robson et al., 1995), EBA175 (Gruner etal., 2001b), PfEMP3 (Gruner et al., 2001a), and HSP70.1 (Renia et al., 1991), which are also expressed during the liver stage.

To screen for protective pre-erythrocytic antigens, it is essential to have the appropriate sera sets against which the library of malarial antigens will be screened. While sera from chronically exposed individuals living in endemic regions are relatively easier to obtain, they are more likely to have an antibody repertoire that is predominantly specific for blood stage antigens, hence might not be suitable for the identification of liver stage antigens. Marchand and Druilhe (1990) and Gruner et al. (2003) were the first to show in human that chloroquine prophylaxis protected against blood stage infection and use the protected sera to screen for protective antigens. This led to the identification of liver-specific (LSA1; Guerin-Marchand et al., 1987) or cross stagespecific antigens stages (LSA-3, STARP, and SALSA; Fidock et al., 1994; Bottius et al., 1996; Daubersies et al., 2000). Recently, the studies by Trieu et al. (2011) and Chia et al. (2014) involved the use of sera from animals immunized with sporozoites. Trieu et al. (2011) identified 16 previously uncharacterized pre-erythrocytic antigens (Trieu et al., 2011), while the pre-erythrocytic MAEBL antigen was identified by Chia et al. (2014).

\section{CONCLUSION}

Historically, vaccine development efforts have been focused on immunodominant antigens as vaccine candidates such as merozoite or sporozoite surface proteins. However, the success has been limited thus far.

More recently, through the use of new technologies, immunoscreens have become more comprehensive, and has revealed the strong association of non-immunodominant malarial antigens with protection. Antigen libraries, expressed in bacterial, mammalian, or wheat germ cell-free expression systems, are created either as DNA libraries, recombinant proteins or on cell surface as antigen-presenting cells. In the screening of these antigen libraries for protective antigens, immune sera are an important tool. The type of immune sera chosen for the screening is critical. Carefully planned vaccination trials with an experimental challenge provide differential groups of sera from protected versus non-protected vaccinated individuals to identify protective antigens. Sera from chronically exposed individuals living in malaria-endemic regions have been also used in studies to screen for protective antigens. While sera from these individuals inform about naturally acquired immunity, it is essential to differentiate between the susceptible and the resistant individuals in these naturally exposed individuals. These differential sera allow the exclusion of immunodominant antigens, and inclusion of the non-immunodominant antigens that are associated with protection.

Taken together, the current consensus is protection against malaria is attributed to robust humoral responses directed against a panel of various non-variant antigens instead of only a single or a few immunodominant antigens. Studies to validate the feasibility of these minor non-immunodominant antigens as vaccine candidates should be prioritized for vaccine development against malarial infections. In addition, understanding antigen recognition is an essential step for the establishment of key immune correlates of protection against malarial infections, which would aid greatly in validating vaccine efficacy.

\section{ACKNOWLEDGMENTS}

This work was supported by an intramural grant from Singapore's Agency for Science, Technology and Research. Wan Ni Chia is supported by a postgraduate scholarship from the Yong Loo Lin School of Medicine, National University of Singapore (Singapore).

\section{REFERENCES}

Agnandji, S. T., Lell, B., Fernandes, J. F., Abossolo, B. P., Methogo, B. G., Kabwende, A. L., etal. (2012). A phase 3 trial of RTS,S/AS01 malaria vaccine in African infants. N. Engl. J. Med. 367, 2284-2295. doi: 10.1056/NEJMoa1208394

Agnandji, S. T., Lell, B., Soulanoudjingar, S. S., Fernandes, J. F., Abossolo, B. P., Conzelmann, C., et al. (2011). First results of phase 3 trial of RTS,S/AS01 malaria vaccine in African children. N. Engl. J. Med. 365, 1863-1875. doi: 10.1056/NEJMoa1102287

Amino, R., Thiberge, S., Martin, B., Celli, S., Shorte, S., Frischknecht, F., et al. (2006). Quantitative imaging of Plasmodium transmission from mosquito to mammal. Nat. Med. 12, 220-224. doi: 10.1038/nm1350

Anders, R. F. (1986). Multiple cross-reactivities amongst antigens of Plasmodium falciparum impair the development of protective immunity against malaria. Parasite Immunol. 8, 529-539. doi: 10.1111/j.1365-3024.1986.tb00867.x

Anders, R. F., Coppel, R. L., Brown, G. V., Saint, R. B., Cowman, A. F., Lingelbach, K. R., et al. (1984). Plasmodium falciparum complementary DNA clones expressed in Escherichia coli encode many distinct antigens. Mol. Biol. Med. 2, 177-191.

Ardeshir, F., Flint, J. E., and Reese, R. T. (1985). Expression of Plasmodium falciparum surface antigens in Escherichia coli. Proc. Natl. Acad. Sci. U.S.A. 82, 2518-2522. doi: 10.1073/pnas.82.8.2518

Ashley, E. A., Dhorda, M., Fairhurst, R. M., Amaratunga, C., Lim, P., Suon, S., et al. (2014). Spread of artemisinin resistance in Plasmodium falciparum malaria. N. Engl. J. Med. 371, 411-423. doi: 10.1056/NEJMoa1314981

Baer, K., Klotz, C., Kappe, S. H., Schnieder, T., and Frevert, U. (2007). Release of hepatic Plasmodium yoelii merozoites into the pulmonary microvasculature. PLoS Pathog. 3:e171. doi: 10.1371/journal.ppat.0030171

Barry, A. E., Trieu, A., Fowkes, F. J., Pablo, J., Kalantari-Dehaghi, M., Jasinskas, A., et al. (2011). The stability and complexity of antibody responses to the major 
surface antigen of Plasmodium falciparum are associated with age in a malaria endemic area. Mol. Cell. Proteomics 10:M111. doi: 10.1074/mcp.M111.008326

Baum, E., Badu, K., Molina, D. M., Liang, X., Felgner, P. L., and Yan, G. (2013). Protein microarray analysis of antibody responses to Plasmodium falciparum in western Kenyan highland sites with differing transmission levels. PLoS ONE 8:e82246. doi: 10.1371/journal.pone.0082246

Bejon, P., White, M. T., Olotu, A., Bojang, K., Lusingu, J. P., Salim, N., et al. (2013). Efficacy of RTS,S malaria vaccines: individual-participant pooled analysis of phase 2 data. Lancet Infect. Dis. 13, 319-327. doi: 10.1016/S1473-3099(13) 70005-7

Belnoue, E., Kayibanda, M., Vigario, A. M., Deschemin, J. C., Van Rooijen, N., Viguier, M., et al. (2002). On the pathogenic role of brain-sequestered alphabeta CD8+ T cells in experimental cerebral malaria. J. Immunol. 169, 6369-6375. doi: 10.4049/jimmunol.169.11.6369

Belnoue, E., Voza, T., Costa, F. T., Gruner, A. C., Mauduit, M., Rosa, D. S., et al. (2008). Vaccination with live Plasmodium yoelii blood stage parasites under chloroquine cover induces cross-stage immunity against malaria liver stage. J. Immunol. 181, 8552-8558. doi: 10.4049/jimmunol.181.12.8552

Bottius, E., Benmohamed, L., Brahimi, K., Gras, H., Lepers, J. P., Raharimalala, L. et al. (1996). A novel Plasmodium falciparum sporozoite and liver stage antigen (SALSA) defines major B, T helper, and CTL epitopes. J. Immunol. 156, 2874 2884.

Bouharoun-Tayoun, H., Oeuvray, C., Lunel, F., and Druilhe, P. (1995). Mechanisms underlying the monocyte-mediated antibody-dependent killing of Plas modium falciparum asexual blood stages. J. Exp. Med. 182, 409-418. doi: 10.1084/jem.182.2.409

Bozdech, Z., Llinas, M., Pulliam, B. L., Wong, E. D., Zhu, J., and Derisi, J. L. (2003). The transcriptome of the intraerythrocytic developmental cycle of Plasmodium falciparum. PLoS Biol. 1:E5. doi: 10.1371/journal.pbio.0000005

Brown, G. V., Anders, R. F., Coppel, R. L., Saint, R. B., Cowman, A. F., Stahl, H. D., et al. (1984). The expression of Plasmodium falciparum bloodstage antigens in Escherichia coli. Philos. Trans. R. Soc. Lond. B Biol. Sci. 307, 179-187. doi: 10.1098/rstb.1984.0118

Butler, N. S., Vaughan, A. M., Harty, J. T., and Kappe, S. H. (2012). Whole parasite vaccination approaches for prevention of malaria infection. Trends Immunol. 33 247-254. doi: 10.1016/j.it.2012.02.001

Carlton, J. M., Angiuoli, S. V., Suh, B. B., Kooij, T. W., Pertea, M., Silva, J. C., et al (2002). Genome sequence and comparative analysis of the model rodent malaria parasite Plasmodium yoelii yoelii. Nature 419, 512-519. doi: 10.1038/nature 01099

CDC. (2012). Impact of Malaria [Online]. Available at: http://www.cdc.gov/malaria/ malaria_worldwide/impact.html [Accessed Feb 14, 2014].

Chia, W., Asm, O., Ksw, T., Preiser, P., and Renia, L. (2014). "Defining immune correlates of protection against malaria using Plasmodium yoelii mouse models," in Australian Society of Parasitology Annual Conference, Canberra.

Clyde, D. F., Most, H., Mccarthy, V. C., and Vanderberg, J. P. (1973). Immunization of man against sporozite-induced falciparum malaria. Am. J. Med. Sci. 266, 169-177. doi: 10.1097/00000441-197309000-00002

Cockburn, I. A., Amino, R., Kelemen, R. K., Kuo, S. C., Tse, S. W., Radtke, A., et al. (2013). In vivo imaging of CD8+ $\mathrm{T}$ cell-mediated elimination of malaria liver stages. Proc. Natl. Acad. Sci. U.S.A. 110, 9090-9095. doi: 10.1073/pnas. 1303858110

Cohen, S., Mc, G. I., and Carrington, S. (1961). Gamma-globulin and acquired immunity to human malaria. Nature 192, 733-737. doi: 10.1038/192733a0

Crompton, P. D., Kayala, M. A., Traore, B., Kayentao, K., Ongoiba, A., Weiss, G. E., et al. (2010). A prospective analysis of the Ab response to Plasmodium falciparum before and after a malaria season by protein microarray. Proc. Natl. Acad. Sci. U.S.A. 107, 6958-6963. doi: 10.1073/pnas.1001323107

Crosnier, C., Bustamante, L. Y., Bartholdson, S. J., Bei, A. K., Theron, M., Uchikawa, M., etal. (2011). Basigin is a receptor essential for erythrocyte invasion by Plasmodium falciparum. Nature 480, 534-537. doi: 10.1038/nature 10606

Daubersies, P., Thomas, A. W., Millet, P., Brahimi, K., Langermans, J. A., Ollomo, B. et al. (2000). Protection against Plasmodium falciparum malaria in chimpanzees by immunization with the conserved pre-erythrocytic liver-stage antigen 3 . Nat. Med. 6, 1258-1263. doi: 10.1038/81366

Doolan, D. L. (2011). Plasmodium immunomics. Int. J. Parasitol. 41, 3-20. doi: 10.1016/j.ijpara.2010.08.002
Doolan, D. L., and Hoffman, S. L. (2000). The complexity of protective immunity against liver-stage malaria. J. Immunol. 165, 1453-1462. doi: 10.4049/jimmunol.165.3.1453

Doolan, D. L., Mu, Y., Unal, B., Sundaresh, S., Hirst, S., Valdez, C., et al. (2008). Profiling humoral immune responses to Plasmodium falciparum infection with protein microarrays. Proteomics 8, 4680-4694. doi: 10.1002/pmic.200800194

Doolan, D. L., Southwood, S., Freilich, D. A., Sidney, J., Graber, N. L., Shatney, L., et al. (2003). Identification of Plasmodium falciparum antigens by antigenic analysis of genomic and proteomic data. Proc. Natl. Acad. Sci. U.S.A. 100, 99529957. doi: 10.1073/pnas.1633254100

Dutta, S., Haynes, J. D., Barbosa, A., Ware, L. A., Snavely, J. D., Moch, J. K., et al. (2005). Mode of action of invasion-inhibitory antibodies directed against apical membrane antigen 1 of Plasmodium falciparum. Infect. Immun. 73, 2116-2122. doi: 10.1128/IAI.73.4.2116-2122.2005

Ellis, J., Ozaki, L. S., Gwadz, R. W., Cochrane, A. H., Nussenzweig, V., Nussenzweig, R. S., et al. (1983). Cloning and expression in E. coli of the malarial sporozoite surface antigen gene from Plasmodium knowlesi. Nature 302, 536-538. doi: $10.1038 / 302536 \mathrm{a} 0$

Fidock, D. A., Sallenave-Sales, S., Sherwood, J. A., Gachihi, G. S., Ferreira-DaCruz, M. F., Thomas, A. W., et al. (1994). Conservation of the Plasmodium falciparum sporozoite surface protein gene, STARP, in field isolates and distinct species of Plasmodium. Mol. Biochem. Parasitol. 67, 255-267. doi: 10.1016/0166-6851(94)00138-3

Finney, O. C., Keitany, G. J., Smithers, H., Kaushansky, A., Kappe, S., and Wang, R. (2014). Immunization with genetically attenuated Plasmodium falciparum parasites induces long-lived antibodies that efficiently block hepatocyte invasion by sporozoites. Vaccine 32, 2135-2138. doi: 10.1016/j.vaccine.2014.02.055

Florens, L., Washburn, M. P., Raine, J. D., Anthony, R. M., Grainger, M., Haynes, J. D., et al. (2002). A proteomic view of the Plasmodium falciparum life cycle. Nature 419, 520-526. doi: 10.1038/nature01107

Frevert, U., Moreno, A., Calvo-Calle, M., Klotz, C., and Nardin, E. H. (2009). Imaging effector functions of human cytotoxic CD4+ T cells specific for Plasmodium falciparum circumsporozoite protein. Int. J. Parasitol. 39, 119-132. doi: 10.1016/j.ijpara.2008.06.014

Friesen, J., Silvie, O., Putrianti, E. D., Hafalla, J. C., Matuschewski, K., and Borrmann, S. (2010). Natural immunization against malaria: causal prophylaxis with antibiotics. Sci. Transl. Med. 2, 40-49. doi: 10.1126/scitranslmed. 3001058

Gardner, M. J., Hall, N., Fung, E., White, O., Berriman, M., Hyman, R. W., et al. (2002). Genome sequence of the human malaria parasite Plasmodium falciparum. Nature 419, 498-511. doi: 10.1038/nature01097

Gruner, A. C., Brahimi, K., Eling, W., Konings, R., Meis, J., Aikawa, M., et al. (2001a). The Plasmodium falciparum knob-associated PfEMP3 antigen is also expressed at pre-erythrocytic stages and induces antibodies which inhibit sporozoite invasion. Mol. Biochem. Parasitol. 112, 253-261. doi: 10.1016/S0166-6851(00) 00373-X

Gruner, A. C., Brahimi, K., Letourneur, F., Renia, L., Eling, W., Snounou, G., et al. (2001b). Expression of the erythrocyte-binding antigen 175 in sporozoites and in liver stages of Plasmodium falciparum. J. Infect. Dis. 184, 892-897. doi: $10.1086 / 323394$

Gruner, A. C., Snounou, G., Brahimi, K., Letourneur, F., Renia, L., and Druilhe, P. (2003). Pre-erythrocytic antigens of Plasmodium falciparum: from rags to riches? Trends Parasitol. 19, 74-78. doi: 10.1016/j.ijpara.2004.05.005

Guerin-Marchand, C., Druilhe, P., Galey, B., Londono, A., Patarapotikul, J., Beaudoin, R. L., et al. (1987). A liver-stage-specific antigen of Plasmodium falciparum characterized by gene cloning. Nature 329, 164-167. doi: 10.1038/329164a0

Gupta, S., Snow, R. W., Donnelly, C. A., Marsh, K., and Newbold, C. (1999). Immunity to non-cerebral severe malaria is acquired after one or two infections. Nat. Med. 5, 340-343. doi: 10.1038/6560

Haddad, D., Bilcikova, E., Witney, A. A., Carlton, J. M., White, C. E., Blair, P. L., et al. (2004). Novel antigen identification method for discovery of protective malaria antigens by rapid testing of DNA vaccines encoding exons from the parasite genome. Infect. Immun. 72, 1594-1602. doi: 10.1128/IAI.72.3.1594-1602.2004

Hall, N., Karras, M., Raine, J. D., Carlton, J. M., Kooij, T. W., Berriman, M., etal. (2005). A comprehensive survey of the Plasmodium life cycle by genomic, transcriptomic, and proteomic analyses. Science 307, 82-86. doi: $10.1126 /$ science. 1103717 
Hall, N., Pain, A., Berriman, M., Churcher, C., Harris, B., Harris, D., et al. (2002). Sequence of Plasmodium falciparum chromosomes 1, 3-9 and 13. Nature 419, 527-531. doi: 10.1038/nature01095

Hoffman, S. L., Goh, L. M., Luke, T. C., Schneider, I., Le, T. P., Doolan, D. L., et al. (2002). Protection of humans against malaria by immunization with radiationattenuated Plasmodium falciparum sporozoites. J. Infect. Dis. 185, 1155-1164. doi: 10.1086/339409

Horne-Debets, J. M., Faleiro, R., Karunarathne, D. S., Liu, X. Q., Lineburg, K. E., Poh, C. M., et al. (2013). PD-1 dependent exhaustion of CD8+ T cells drives chronic malaria. Cell Rep. 5, 1204-1213. doi: 10.1016/j.celrep.2013.11.002

Jiang, L., Gaur, D., Mu, J., Zhou, H., Long, C. A., and Miller, L. H. (2011). Evidence for erythrocyte-binding antigen 175 as a component of a ligand-blocking blood-stage malaria vaccine. Proc. Natl. Acad. Sci. U.S.A. 108, 7553-7558. doi: 10.1073/pnas. 1104050108

Kamali, A. N., Marin-Garcia, P., Azcarate, I. G., Diez, A., Puyet, A., and Bautista, J. M. (2012). Plasmodium yoelii blood-stage antigens newly identified by immunoaffinity using purified IgG antibodies from malaria-resistant mice. Immunobiology 217, 823-830. doi: 10.1016/j.imbio.2012.05.002

Kappe, S. H., Gardner, M. J., Brown, S. M., Ross, J., Matuschewski, K., Ribeiro, J. M., etal. (2001). Exploring the transcriptome of the malaria sporozoite stage. Proc. Natl. Acad. Sci. U.S.A. 98, 9895-9900. doi: 10.1073/pnas.1711 85198

Kappe, S. H., Noe, A. R., Fraser, T. S., Blair, P. L., and Adams, J. H. (1998). A family of chimeric erythrocyte binding proteins of malaria parasites. Proc. Natl. Acad. Sci. U.S.A. 95, 1230-1235. doi: 10.1073/pnas.95.3.1230

Kemp, D. J., Coppel, R. L., and Anders, R. F. (1987). Repetitive proteins and genes of malaria. Annu. Rev. Microbiol. 41, 181-208. doi: 10.1146/annurev.mi.41.100187.001145

Kemp, D. J., Coppel, R. L., Cowman, A. F., Saint, R. B., Brown, G. V., and Anders, R. F. (1983). Expression of Plasmodium falciparum blood-stage antigens in Escherichia coli: detection with antibodies from immune humans. Proc. Natl. Acad. Sci. U.S.A. 80, 3787-3791. doi: 10.1073/pnas.80.12.3787

Kemp, D. J., Coppel, R. L., Stahl, H. D., Bianco, A. E., Corcoran, L. M., Mcintyre, P., et al. (1986). The wellcome trust lecture. Genes for antigens of Plasmodium falciparum. Parasitology 92(Suppl.), S83-S108. doi: 10.1017/S00311820000 85711

Khan, S. M., Franke-Fayard, B., Mair, G. R., Lasonder, E., Janse, C. J., Mann, M., etal. (2005). Proteome analysis of separated male and female gametocytes reveals novel sex-specific Plasmodium biology. Cell 121, 675-687. doi: 10.1016/j.cell.2005.03.027

Kooij, T. W., Carlton, J. M. R., Bidwell, S. L., Hall, N., Ramesar, J., Janse, C. J., et al. (2005). A Plasmodium whole-genome synteny map: indels and synteny breakpoints as foci for species-specific genes. PLoS Pathog. 1:e44. doi: 10.1371/journal.ppat.0010044

Langhorne, J. (1994). The immune response to the blood stages of Plasmodium in animal models. Immunol. Lett. 41, 99-102. doi: 10.1016/0165-2478(94)90115-5

Langhorne, J., Ndungu, F. M., Sponaas, A. M., and Marsh, K. (2008). Immunity to malaria: more questions than answers. Nat. Immunol. 9, 725-732. doi 10.1038/ni.f.205

Lasonder, E., Ishihama, Y., Andersen, J. S., Vermunt, A. M., Pain, A., Sauerwein, R. W., et al. (2002). Analysis of the Plasmodium falciparum proteome by high-accuracy mass spectrometry. Nature 419, 537-542. doi: 10.1038/nature01111

Le Roch, K. G., Zhou, Y., Batalov, S., and Winzeler, E. A. (2002). Monitoring the chromosome 2 intraerythrocytic transcriptome of Plasmodium falciparum using oligonucleotide arrays. Am. J. Trop. Med. Hyg. 67, 233-243.

Lindner, S. E., Swearingen, K. E., Harupa, A., Vaughan, A. M., Sinnis, P., Moritz, R. L., et al. (2013). Total and putative surface proteomics of malaria parasite salivary gland sporozoites. Mol. Cell. Proteomics 12, 1127-1143. doi: 10.1074/mcp.M112.024505

Lu, F., Li, J., Wang, B., Cheng, Y., Kong, D. H., Cui, L., et al. (2014). Profiling the humoral immune responses to Plasmodium vivax infection and identification of candidate immunogenic rhoptry-associated membrane antigen (RAMA). $J$. Proteomics 6, 66-82. doi: 10.1016/j.jprot.2014.02.029

Marchand, C., and Druilhe, P. (1990). How to select Plasmodium falciparum preerythrocytic antigens in an expression library without defined probe. Bull. World Health Organ. 68(Suppl.), 158-164.

Marsh, K., and Kinyanjui, S. (2006). Immune effector mechanisms in malaria. Parasite Immunol. 28, 51-60. doi: 10.1111/j.1365-3024.2006.00808.x
Mehlin, C., Boni, E., Buckner, F. S., Engel, L., Feist, T., Gelb, M. H., et al. (2006). Heterologous expression of proteins from Plasmodium falciparum: results from 1000 genes. Mol. Biochem. Parasitol. 148, 144-160. doi: 10.1016/j.molbiopara.2006.03.011

Michon, P., Fraser, T., and Adams, J. H. (2000). Naturally acquired and vaccineelicited antibodies block erythrocyte cytoadherence of the Plasmodium vivax Duffy binding protein. Infect. Immun. 68, 3164-3171. doi: 10.1128/IAI.68.6.31643171.2000

Molina, D. M., Finney, O. C., Arevalo-Herrera, M., Herrera, S., Felgner, P. L., Gardner, M. J., et al. (2012). Plasmodium vivax pre-erythrocytic-stage antigen discovery: exploiting naturally acquired humoral responses. Am. J. Trop. Med. Hyg. 87, 460-469. doi: 10.4269/ajtmh.2012.12-0222

Moorthy, V. S., Good, M. F., and Hill, A. V. (2004). Malaria vaccine developments. Lancet 363, 150-156. doi: 10.1016/S0140-6736(03) 15267-1

Mueller, A. K., Labaied, M., Kappe, S. H., and Matuschewski, K. (2005). Genetically modified Plasmodium parasites as a protective experimental malaria vaccine. Nature 433, 164-167. doi: 10.1038/nature03188

Nussenzweig, R. S., Vanderberg, J., Most, H., and Orton, C. (1967). Protective immunity produced by the injection of $\mathrm{x}$-irradiated sporozoites of Plasmodium berghei. Nature 216, 160-162. doi: 10.1038/216160a0

Offeddu, V., Thathy, V., Marsh, K., and Matuschewski, K. (2012). Naturally acquired immune responses against Plasmodium falciparum sporozoites and liver infection. Int. J. Parasitol. 42, 535-548. doi: 10.1016/j.ijpara.2012. 03.011

Olotu, A., Fegan, G., Wambua, J., Nyangweso, G., Awuondo, K. O., Leach, A., et al. (2013). Four-year efficacy of RTS,S/AS01E and its interaction with malaria exposure. N. Engl. J. Med. 368, 1111-1120. doi: 10.1056/NEJMoa 1207564

Osier, F. H., Mackinnon, M. J., Crosnier, C., Fegan, G., Kamuyu, G., Wanaguru, M., et al. (2014). New antigens for a multicomponent blood-stage malaria vaccine. Sci. Transl. Med. 6, 247-102. doi: 10.1126/scitranslmed. 3008705

Overstreet, M. G., Cockburn, I. A., Chen, Y. C., and Zavala, F. (2008). Protective CD8 T cells against Plasmodium liver stages: immunobiology of an 'unnatural' immune response. Immunol. Rev. 225, 272-283. doi: 10.1111/j.1600-065X.2008. 00671.x

Phyo, A. P., Nkhoma, S., Stepniewska, K., Ashley, E. A., Nair, S., Mcgready, R., et al. (2012). Emergence of artemisinin-resistant malaria on the western border of Thailand: a longitudinal study. Lancet 379, 1960-1966. doi: 10.1016/S01406736(12)60484-X

Raj, D. K., Nixon, C. P., Nixon, C. E., Dvorin, J. D., Dipetrillo, C. G., Pond-Tor, S., et al. (2014). Antibodies to PfSEA-1 block parasite egress from RBCs and protect against malaria infection. Science 344, 871-877. doi: 10.1126/science. 1254417

Rathore, D., Nagarkatti, R., Jani, D., Chattopadhyay, R., De La Vega, P., Kumar, S., et al. (2005). An immunologically cryptic epitope of Plasmodium falciparum circumsporozoite protein facilitates liver cell recognition and induces protective antibodies that block liver cell invasion. J. Biol. Chem. 280, 20524-20529. doi: 10.1074/jbc.M414254200

Renia, L., Grillot, D., Marussig, M., Corradin, G., Miltgen, F., Lambert, P. H., et al. (1993). Effector functions of circumsporozoite peptide-primed CD4+ T cell clones against Plasmodium yoelii liver stages. J. Immunol. 150, 1471-1478.

Renia, L., Gruner, A. C., Mauduit, M., and Snounou, G. (2006). Vaccination against malaria with live parasites. Expert Rev. Vaccines 5, 473-481. doi: 10.1586/14760584.5.4.473

Renia, L., Marussig, M. S., Grillot, D., Pied, S., Corradin, G., Miltgen, F., et al. (1991). In vitro activity of CD4+ and CD8+ T lymphocytes from mice immunized with a synthetic malaria peptide. Proc. Natl. Acad. Sci. U.S.A. 88, 7963-7967. doi: 10.1073/pnas.88.18.7963

Renia, L., Mattei, D., Goma, J., Pied, S., Dubois, P., Miltgen, F., et al. (1990). A malaria heat-shock-like determinant expressed on the infected hepatocyte surface is the target of antibody-dependent cell-mediated cytotoxic mechanisms by nonparenchymal liver cells. Eur. J. Immunol. 20, 1445-1449. doi: 10.1002/eji.1830200706

Richards, J. S., Arumugam, T. U., Reiling, L., Healer, J., Hodder, A. N., Fowkes, F. J., etal. (2013). Identification and prioritization of merozoite antigens 
as targets of protective human immunity to Plasmodium falciparum malaria for vaccine and biomarker development. J. Immunol. 191, 795-809. doi: 10.4049/jimmunol.1300778

Richards, W. H. (1966). Antimalarial activity of sulphonamides and a sulphone, singly and in combination with pyrimethamine, against drug resistant and normal strains of laboratory plasmodia. Nature 212, 1494-1495. doi: 10.1038/212 $1494 \mathrm{a} 0$

Rieckmann, K. H., Carson, P. E., Beaudoin, R. L., Cassells, J. S., and Sell, K. W. (1974). Letter: sporozoite induced immunity in man against an Ethiopian strain of Plasmodium falciparum. Trans. R. Soc. Trop. Med. Hyg. 68, 258-259. doi: 10.1016/0035-9203(74)90129-1

Robson, K. J., Frevert, U., Reckmann, I., Cowan, G., Beier, J., Scragg, I. G., et al. (1995). Thrombospondin-related adhesive protein (TRAP) of Plasmodium falciparum: expression during sporozoite ontogeny and binding to human hepatocytes. EMBO J. 14, 3883-3894.

Rodriguez, L. E., Curtidor, H., Urquiza, M., Cifuentes, G., Reyes, C., and Patarroyo, M. E. (2008). Intimate molecular interactions of Plasmodium falciparum merozoite proteins involved in invasion of red blood cells and their implications for vaccine design. Chem. Rev. 108, 3656-3705. doi: 10.1021/cr068407v

Roestenberg, M., Mccall, M., Hopman, J., Wiersma, J., Luty, A. J., Van Gemert, G. J., et al. (2009). Protection against a malaria challenge by sporozoite inoculation. $N$. Engl. J. Med. 361, 468-477. doi: 10.1056/NEJMoa0805832

Rui, E., Fernandez-Becerra, C., Takeo, S., Sanz, S., Lacerda, M. V., Tsuboi, T., et al. (2011). Plasmodium vivax: comparison of immunogenicity among proteins expressed in the cell-free systems of Escherichia coli and wheat germ by suspension array assays. Malar. J. 10, 192. doi: 10.1186/1475-2875-10-192

Schofield, L., and Mueller, I. (2006). Clinical immunity to malaria. Curr. Mol. Med. 6, 205-221. doi: 10.2174/156652406776055221

Seder, R. A., Chang, L. J., Enama, M. E., Zephir, K. L., Sarwar, U. N., Gordon, I. J., et al. (2013). Protection against malaria by intravenous immunization with a nonreplicating sporozoite vaccine. Science 341, 1359-1365. doi: $10.1126 /$ science. 1241800

Sheehy, S. H., Duncan, C. J., Elias, S. C., Choudhary, P., Biswas, S., Halstead, F. D., etal. (2012). ChAd63-MVA-vectored blood-stage malaria vaccines targeting MSP1 and AMA1: assessment of efficacy against mosquito bite challenge in humans. Mol. Ther. 20, 2355-2368. doi: 10.1038/mt. 2012.223

Silvie, O., Franetich, J. F., Charrin, S., Mueller, M. S., Siau, A., Bodescot, M., et al. (2004). A role for apical membrane antigen 1 during invasion of hepatocytes by Plasmodium falciparum sporozoites. J. Biol. Chem. 279, 9490-9496. doi: 10.1074/jbc.M311331200

Singh, N., Preiser, P., Renia, L., Balu, B., Barnwell, J., Blair, P., et al. (2004). Conservation and developmental control of alternative splicing in maeb among malaria parasites. J. Mol. Biol. 343, 589-599. doi: 10.1016/j.jmb.2004. 08.047

Spring, M., Murphy, J., Nielsen, R., Dowler, M., Bennett, J. W., Zarling, S., etal. (2013). First-in-human evaluation of genetically attenuated Plasmodium falciparum sporozoites administered by bite of Anopheles mosquitoes to adult volunteers. Vaccine 31, 4975-4983. doi: 10.1016/j.vaccine.2013. 08.007

Spring, M. D., Cummings, J. F., Ockenhouse, C. F., Dutta, S., Reidler, R., Angov, E., et al. (2009). Phase 1/2a study of the malaria vaccine candidate apical membrane antigen-1 (AMA-1) administered in adjuvant system AS01B or AS02A. PLoS ONE 4:e5254. doi: 10.1371/journal.pone.0005254

Stahl, H. D., Coppel, R. L., Brown, G. V., Saint, R., Lingelbach, K., Cowman, A. F., et al. (1984). Differential antibody screening of cloned Plasmodium falciparum sequences expressed in Escherichia coli: procedure for isolation of defined antigens and analysis of human antisera. Proc. Natl. Acad. Sci. U.S.A. 81, 2456-2460. doi: $10.1073 /$ pnas.81.8.2456
Stevenson, M. M., and Riley, E. M. (2004). Innate immunity to malaria. Nat. Rev. Immunol. 4, 169-180. doi: 10.1038/nri1311

Sturm, A., Amino, R., Van De Sand, C., Regen, T., Retzlaff, S., Rennenberg, A., et al. (2006). Manipulation of host hepatocytes by the malaria parasite for delivery into liver sinusoids. Science 313, 1287-1290. doi: 10.1126/science. 1129720

Tachibana, S., Sullivan, S. A., Kawai, S., Nakamura, S., Kim, H. R., Goto, N., et al. (2012). Plasmodium cynomolgi genome sequences provide insight into Plasmodium vivax and the monkey malaria clade. Nat. Genet. 44, 1051-1055. doi: 10.1038/ng.2375

Tarun, A. S., Peng, X., Dumpit, R. F., Ogata, Y., Silva-Rivera, H., Camargo, N., et al. (2008). A combined transcriptome and proteome survey of malaria parasite liver stages. Proc. Natl. Acad. Sci. U.S.A. 105, 305-310. doi: 10.1073/pnas.0710 780104

Taylor-Robinson, A. W. (2010). Regulation of immunity to Plasmodium: implications from mouse models for blood stage malaria vaccine design. Exp. Parasitol. 126, 406-414. doi: 10.1016/j.exppara.2010.01.028

Trape, J. F., Tall, A., Diagne, N., Ndiath, O., Ly, A. B., Faye, J., et al. (2011). Malaria morbidity and pyrethroid resistance after the introduction of insecticide-treated bednets and artemisinin-based combination therapies: a longitudinal study. Lancet Infect. Dis. 11, 925-932. doi: 10.1016/S1473-3099(11) 70194-3

Trieu, A., Kayala, M. A., Burk, C., Molina, D. M., Freilich, D. A., Richie, T. L., et al. (2011). Sterile protective immunity to malaria is associated with a panel of novel Plasmodium falciparum antigens. Mol. Cell. Proteomics 10, M111 007948. doi: 10.1074/mcp.M111.007948

Trimnell, A., Takagi, A., Gupta, M., Richie, T. L., Kappe, S. H., and Wang, R. (2009). Genetically attenuated parasite vaccines induce contact-dependent CD8+ T cell killing of Plasmodium yoelii liver stage-infected hepatocytes. J. Immunol. 183, 5870-5878. doi: 10.4049/jimmunol.0900302

Tsuboi, T., Takeo, S., Iriko, H., Jin, L., Tsuchimochi, M., Matsuda, S., et al. (2008). Wheat germ cell-free system-based production of malaria proteins for discovery of novel vaccine candidates. Infect. Immun. 76, 1702-1708. doi: 10.1128/IAI.01539-07

Vanderberg, J. P., and Frevert, U. (2004). Intravital microscopy demonstrating antibody-mediated immobilization of Plasmodium berghei sporozoites injected into skin by mosquitoes. Int. J. Parasitol. 34, 991-996. doi: 10.1016/j.ijpara.2004.05.005

WHO. (2012). Malaria Vaccine Rainbow Tables. Available at: www.who.int/vaccine research/links/Rainbow/en/index.html [accessed June 30, 2014].

Wykes, M. N., and Good, M. F. (2009). What have we learnt from mouse models for the study of malaria? Eur. J. Immunol. 39, 2004-2007. doi: 10.1002/eji.200939552

Conflict of Interest Statement: The authors declare that the research was conducted in the absence of any commercial or financial relationships that could be construed as a potential conflict of interest.

Received: 19 August 2014; accepted: 17 October 2014; published online: 17 November 2014.

Citation: Chia WN, Goh YS and Rénia L (2014) Novel approaches to identify protective malaria vaccine candidates. Front. Microbiol. 5:586. doi: 10.3389/fmicb.2014.00586

This article was submitted to Microbial Immunology, a section of the journal Frontiers in Microbiology.

Copyright ( $(2014$ Chia, Goh and Rénia. This is an open-access article distributed under the terms of the Creative Commons Attribution License (CC BY). The use, distribution or reproduction in other forums is permitted, provided the original author(s) or licensor are credited and that the original publication in this journal is cited, in accordance with accepted academic practice. No use, distribution or reproduction is permitted which does not comply with these terms. 